\title{
脳外傷者に対する通院プログラムの試み
}

\author{
橋本圭司*1 渡邊 修*5 大橋 正洋*1 \\ 殿 村 曉*2 藤縄 光留*3 生方 克之*4
}

\section{Efficacy of a Day Treatment Program for the Rehabilitation of Traumatic Brain Injury Patients}

\author{
Keiji Hashimoto, ${ }^{* 1}$ Shu Watanabe, ${ }^{* 5}$ Masahiro Ohashi, ${ }^{* 1}$ \\ Satoru Tonomura, ${ }^{* 2}$ Mitsuru Fujinawa, ${ }^{* 3}$ Katsuyuki Ubukata*4
}

\begin{abstract}
The objective of this study is to assess the effectiveness of a day treatment program offered by the Kanagawa Rehabilitation Hospital that is a comprehensive team approach for treating traumatic brain injury (TBI) outpatients. We performed a prospective study using 18 TBI patients with cognitive impairment who were treated at the Kanagawa Rehabilitation Hospital. We applied neuropsychological tests, Functional Independence Measure/Functional Assessment Measure (FIM/FAM) and a Community Integration Questionnaire (CIQ) at the initiation of this program. To assess the effectiveness of this program, the outcomes of these 18 patients were compared with the outcomes of 12 control patients. The eighteen patients enrolled in this study received 4 sessions for 2 to 4 hours a day, 2 days a week, over a 3 to 6 month period. As a result, significant improvements in attention, social integration scores for FAM, and productive scores for CIQ were evident in the enrolled subjects. In addition, 6 of the 18 patients went back to their former work or school. These results demonstrate the effectiveness of this program in helping TBI patients back to society. (Jpn J Rehabil Med 2003 ; 40 : 699-706)
\end{abstract}

要 旨：当院における脳外傷者の社会復帰支援を目的とした, グループ形式の「通院プログ ラム」の有効性について検討した．対象は同プログラムに参加した脳外傷者 18 名 (平均年齢 26.6 歳, 男性 13 名, 女性 5 名)。この対象群 18 例を, 脳外傷の重症度, 年齢, 受傷からの期 間, FIM 評価点を一致させたコントロール群 12 例と比較した．プログラムは, 2001 年から 2003 年にかけて計 3 回施行し, 多職種が関わり, 週 2 回, 各々 $2 \sim 4$ 時間, $3 \sim 6$ 力月間行っ た. 本プログラムの評価には, FIM・FAM (Functional Independence Measure・Functional Assessment Measure) および社会参加状況について CIQ (Community Integration Questionnaire）を用いた。プログラム前後で参加群とコントロール群を比較したところ， FAM の注意・集中と社会的交流の 2 項目, 加えて CIQ の生産性に有意な改善があった。ま た参加群 18 例中, 6 例が就労・就学を果たした. 脳外傷者に対する, 多職種の関与によるゴ 一ル指向型の外来リハビリテーションプログラムの有効性が示唆された。 今後の課題として, (1)プログラム終了後も長期支援を継続できるシステムの構築, (2)多職種が関与することについ ての費用対効果の検討などがある. (リハ医学 $2003 ; 40: 699-706$ )

2003 年 6 月 2 日受付, 2003 年 8 月 29 日受理

*1 神奈川リハビリテーション病院リハビリテーション科, ${ }^{* 2}$ 心理科, ${ }^{* 3}$ 理学療法科, ${ }^{* 4}$ 相談科/ $/ 243-0121$ 神奈川県厚 木市七沢 516 番地

Department of Rehabilitation Medicine, ${ }^{* 1}$ Department of Psychology, ${ }^{* 2}$ Department of Physical Therapy, ${ }^{* 3}$ Department of Social Work, ${ }^{* 4}$ Kanagawa Rehabilitation Hospital

*5 東京都立保健科学大学/ $1116-8551$ 東京都荒川区東尾久 7-2-10

Tokyo Metropolitan University of Health Sciences 
Key words : 脳外傷 (traumatic brain injury), 高次脳機能障害 (higher brain dysfunction), 通院プログラム (day treatment program), FIM・FAM (Functional Independence Measure $・$ Functional Assessment Measure), リハビ リテーション (rehabilitation)

\section{はじめに}

脳外傷者の社会復帰を考える時, 復学や復職が大き な問題となる ${ }^{1,2)}$. 当院には, 年間約 100 名の脳外傷 者が，リハビリテーション（以下，リハ）目的で入院 治療に訪れている，当院の脳外傷に対するリハプログ ラムは，患者を中心に多職種が各ゴールに向けて，社 会参加を支援し，ライフステージに沿って関わってゆ く comprehensive, holistic アプローチを目指してい る3). その一方で, 入院治療のみではすべての問題を 解決することができず, 引き続き外来でも同様の職種 が継続的に関わるケースも多い。それらの支援を行う 場合, 通院によるグループ形式のリハプログラムが効 果的であるとする報告 ${ }^{48)}$ が過去にもあり, いずれも 就労・就学を 1 つの目標として揭げている.

当院でも，(1) 2001 年 9 月〜2002 年 2 月, (2) 2002 年 7 月〜 10 月, (3) 2003 年 2 月〜 4 月の 3 クールに渡 って, 退院後の脳外傷者を対象としたグループ訓練を 試行し，「通院プログラム」と呼称することにした。 その目的は，(1)量急性期以降の医療体制の継続，(2医 療と福祉, 労働, 教育などの地域との連携の強化, (3) 対人関係スキルの向上である.

既に渡邊 ${ }^{9}$ が, 第 1 期・同プログラムの成果と課題 について報告している. 本論文では, その後 2 期の参 加者を加えた計 18 名の脳外傷者の社会復帰支援を紹 介し, プログラム前後の日常生活自立度, 社会参加状 況の変化を, コントロール群 12 名と比較することで 本プログラムの効果判定を行った.

\section{対象および方法}

対象は脳外傷者 18 名である. 通院プログラム 1 ク ールごとの参加者は 6 名であり，その選考基準は，(1) 歩行・車椅子にかかわらず ADL がほぼ自立してい る, (2)就労・就学を目標としている, (3)当院外来リ八 以外, 具体的通い先が無い症例である. 表 1 亿通院プ ログラム開始時の年齢, 性別, 受傷前の職業, 教育年 数, 受傷時年齢, 受傷原因, 受傷時重症度診断, 受傷 から本プログラム開始までの期間，プログラム開始時 の MRI 所見, 身体所見, Functional Independence
Measure (以下 FIM), WAIS-R (Wechsler Adult Intelligence Scale-Revised）所見を示す。症例 6 以 外は 19 41 歳と比較的若年傾向である. 症例 7 と症 例 16 は車椅子を使用しており日常生活に一部介助を 要するが，その他の 16 名は歩行・日常生活ともに自 立している.いずれの症例も, 受傷後, 急性期病院, 次いで神奈川リハ病院での入院リ八を終了した後, 神 奈川リハ病院外来での個別リハを継続していて，全 例, 復職あるいは復学を希望していた。症例 6 と症例 15 以外の 16 名は, 受傷時の意識障害が GCS（Glasgow Coma Scale) で8点以下または JCS（Japan Coma Scale) で 3 桁であり, Gennarelli の重症度分 類 ${ }^{10)}$ などより, 重症脳外傷例であった。

コントロール群として, 同時期に当院外来通院され ていた脳外傷者 12 名を選択した。この 12 名は，同プ ログラム参加者の選考基準を満たすが，今回はプログ ラムに加わらなかった脳外傷者である。2 群間の年 齢, 受傷からの期間, 重度脳外傷者の割合, FIM/ FAM それぞれの合計点には，統計学的に有意差を認 めなかった（表 2).

通院リハプログラムは，週 2 回，第 1 期は各々 11 時〜 15 時の 4 時間, 第 2 期, 第 3 期は各々 13 時〜 15 時の 2 時間の中で，4つのセッションを設けて施行 し, 第 1 期は 6 力月間，第 2 期は 4 力月間，第 3 期は 3 カ月行った. セッションの内容と担当した職種を表 3 にまとめた.リ八医を統括責任者とし, プログラム の潤滑な運営を目的として, 臨床心理士, 医療ソーシ ヤルワーカー, 理学療法士, 更生施設生活指導員, を それぞれコーディネーターとして配置した。

本プログラムの効果を評価するために，能力障害の 評価として FIM・FAM (Functional Independence Measure • Functional Assessment Measure) を，社 会参加状況の評価として CIQ (Community Integration Questionnaire）を用いた。プログラム参加群と コントロール群の比較は, プログラムとコントロール 群との調查期間を合わせたうえで検討した。

リ八効果の検討は, プログラム開始時の FIM・ FAM，CIQ の評価点が，それぞれ，対象群とコント ロール群に有意差の無いことを前提とし，プログラム 
表 1 通院プログラム参加者のプロフィール

\begin{tabular}{|c|c|c|c|c|c|c|c|c|c|c|c|c|c|}
\hline \multirow[b]{2}{*}{ 1期性 } & \multirow{2}{*}{\begin{tabular}{c|} 
通プロ開始時 \\
年齢 \\
\end{tabular}} & \multirow[b]{2}{*}{ 性別 } & \multirow[b]{2}{*}{ 職業 } & \multirow{2}{*}{$\begin{array}{l}\text { 教育 } \\
\text { 年数 }\end{array}$} & \multirow{2}{*}{$\begin{array}{l}\text { 受罂時 } \\
\text { 年齢 }\end{array}$} & \multirow[b]{2}{*}{ 受稘原因 } & \multicolumn{2}{|c|}{ 受侮時 } & \multirow{2}{*}{ 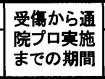 } & \multicolumn{4}{|c|}{ 通院プログラム開始時 } \\
\hline & & & & & & & 重症度 & 診断 & & 挫僎部位(MRI) & \begin{tabular}{|c|} 
身体: \\
通動系 \\
\end{tabular} & FIM & WAIS-R \\
\hline 症例1 & 23歳 & 女性 & 会社員 & 14年 & 23歳 & $\begin{array}{c}\text { 交通事故 } \\
\text { 四輪後部座席 }\end{array}$ & \begin{tabular}{|c|} 
重度 \\
$\mathrm{JCS}=100$
\end{tabular} & DBI & 163日 & \begin{tabular}{|c|} 
左前頭葉 \\
脳梁 \\
左大脳脚 \\
\end{tabular} & $\begin{array}{c}\text { 軽度左側 } \\
\text { 失調 }\end{array}$ & $\begin{array}{l}\text { 運動 } 91 \\
\text { 認知 } 31 \\
\text { 全 } 122 \\
\end{array}$ & $\begin{array}{l}\text { VIQ } 69 \\
\text { PIQ } 64 \\
\text { FIQ } 61 \\
\end{array}$ \\
\hline 症例2 & 34歳 & 男性 & 会社員 & 12年 & 34歳 & $\begin{array}{l}\text { 交通事故 } \\
\text { 歩行者 }\end{array}$ & $\begin{array}{c}\text { 重度 } \\
\text { JCS }=200\end{array}$ & $\begin{array}{c}\text { DBI } \\
\text { rt.AEDH }\end{array}$ & 326日 & $\begin{array}{c}\text { 左前頭葉 } \\
\text { 右側頭葉 } \\
\text { 右頭頂葉 } \\
\text { 左中脳 }\end{array}$ & 右片麻瘦 & $\begin{array}{c}\text { 運動 } 88 \\
\text { 锶知 } 32 \\
\text { 全 } 120 \\
\end{array}$ & $\begin{array}{l}\text { VIQ } 91 \\
\text { PIQ } 67 \\
\text { FIQ } 79 \\
\end{array}$ \\
\hline 症例3 & 30歳 & 男性 & 自営業 & 14年 & 29歳 & $\begin{array}{c}\text { 交通事故 } \\
\text { 四輪運転手 }\end{array}$ & $\begin{array}{c}\text { 重度 } \\
\mathrm{GCS}=6\end{array}$ & DBI & 287日 & $\begin{array}{c}\text { 両側前頭葉 } \\
\text { 脳梁 } \\
\text { 橋 } \\
\text { 両側大脳脚 }\end{array}$ & \begin{tabular}{|c|} 
軽度左片 \\
麻㾝, 禹 \\
側失調, \\
複視
\end{tabular} & $\begin{array}{c}\text { 運動 } 91 \\
\text { 認知 } 27 \\
\text { 全 } 118 \\
\end{array}$ & $\begin{array}{l}\text { VIQ } 71 \\
\text { PIQ } 63 \\
\text { FIQ } 65 \\
\end{array}$ \\
\hline 症例4 & 19歳 & 男性 & 学生 & 13年 & 19歳 & $\begin{array}{l}\text { 交通事故 } \\
\text { 八仍運転 }\end{array}$ & \begin{tabular}{|c|} 
重度 \\
JCS $=100$
\end{tabular} & $\begin{array}{l}\text { DBI } \\
\text { It.ASDH }\end{array}$ & 288日 & $\begin{array}{l}\text { 左頭頂保 } \\
\text { 左後頭葉 } \\
\text { 左被殼 }\end{array}$ & $\begin{array}{c}\text { 右腕神経 } \\
\text { 車損傷 }\end{array}$ & $\begin{array}{l}\text { 運動 } 84 \\
\text { 知 } 23 \\
\text { 全 } 107\end{array}$ & $\begin{array}{c}\text { MMSE } \\
26\end{array}$ \\
\hline 症例5 & 19歳 & 男性 & 学生 & 9年 & 16歳 & $\begin{array}{l}\text { 交通事故 } \\
\text { バ行運転 }\end{array}$ & $\begin{array}{c}\text { 重度 } \\
\text { GCS }=7\end{array}$ & $\begin{array}{c}\text { DBI } \\
\text { rt.ASDH }\end{array}$ & 1123日 & $\begin{array}{l}\text { 右前頭葉 } \\
\text { 右側頭葉 } \\
\text { 右頭頂葉 }\end{array}$ & $\begin{array}{c}\text { 軽度体幹 } \\
\text { 失調 }\end{array}$ & $\begin{array}{c}\text { 運動 } 91 \\
\text { 视知 } 28 \\
\text { 全 } 119\end{array}$ & $\begin{array}{l}\text { VIQ } 68 \\
\text { PIQ } 77 \\
\text { FIQ } 89\end{array}$ \\
\hline 症例6 & 56 歳 & 男性 & 自棠業 & 12年 & 55歳 & 転落 & $\begin{array}{c}\text { 中等度 } \\
\mathrm{JCS}=30\end{array}$ & $\begin{array}{c}\text { DBI } \\
\text { 脳挫傷 } \\
\text { (两側前頭葉) }\end{array}$ & 308日 & $\begin{array}{c}\text { 両側前頭葉 } \\
\text { 右傾葉 } \\
\text { 両側後頭葉 }\end{array}$ & 異常なし & $\begin{array}{ll}\text { 運動 } 91 \\
\text { 諰知 } 29 \\
\text { 全 } 120 \\
\end{array}$ & $\begin{array}{l}\text { VIQ } 91 \\
\text { PIQ } 76 \\
\text { FIQ } 84 \\
\end{array}$ \\
\hline \multirow[b]{2}{*}{ 2期生 } & \multirow{2}{*}{\begin{tabular}{|c|} 
通プロ開始時 \\
年粹
\end{tabular}} & \multirow[b]{2}{*}{ 性別 } & \multirow[b]{2}{*}{ 職業 } & \multirow{2}{*}{$\begin{array}{l}\text { 教育 } \\
\text { 年数 }\end{array}$} & \multirow{2}{*}{$\begin{array}{c}\text { 受㑑時 } \\
\text { 年齢 }\end{array}$} & \multirow[b]{2}{*}{ 受佰原因 } & \multicolumn{2}{|c|}{ 受傷時 } & \multirow{2}{*}{$\begin{array}{l}\text { 受集から通 } \\
\text { 院プロ実施 } \\
\text { までの期間 }\end{array}$} & \multicolumn{4}{|c|}{ 通院プログラム開始時 } \\
\hline & & & & & & & 重症度 & 診断 & & 挫鹪部位(MRI) & \begin{tabular}{|l|} 
身体: \\
通動系 \\
\end{tabular} & FIM & WAIS-R \\
\hline 症例7 & 21歳 & 女性 & |フーー & 12年 & 20歳 & $\begin{array}{l}\text { 交通事故 } \\
\text { ハイイク運転 }\end{array}$ & \begin{tabular}{c|} 
重度 \\
JCS $=200$
\end{tabular} & DBI & 595日 & $\begin{array}{l}\text { 右前頭葉 } \\
\text { 右側頭葉 }\end{array}$ & 左片麻㾝 & $\begin{array}{l}\text { 運動 } 71 \\
\text { 認知 } 31 \\
\text { 全 } 102 \\
\end{array}$ & $\begin{array}{l}\text { VIQ } 71 \\
\text { PIQ } 64 \\
\text { FQ 63 }\end{array}$ \\
\hline 症例8 & 19歳 & 女性 & 学生 & 11 年 & 17歳 & \begin{tabular}{|c|} 
交通事故 \\
ハイク後部座席
\end{tabular} & $\begin{array}{c}\text { 重度 } \\
\text { GCS }=8\end{array}$ & $\begin{array}{c}\text { DBI } \\
\text { rt.ASDH }\end{array}$ & 779日 & $\begin{array}{l}\text { 右側頭葉 } \\
\text { 右頭頂葉 }\end{array}$ & $\begin{array}{l}\text { 両側上肢 } \\
\text { 失調軽度 }\end{array}$ & $\begin{array}{c}\text { 運動 } 91 \\
\text { 認知 } 26 \\
\text { 全 } 117 \\
\end{array}$ & $\begin{array}{l}\text { VIQ } \\
\text { PIQ } \\
\text { FIQ }\end{array}$ \\
\hline 症例9 & 41 歳 & 男性 & 会社員 & 12年 & 40歳 & $\begin{array}{l}\text { 交通事故 } \\
\text { パイク運転 }\end{array}$ & \begin{tabular}{|c|} 
重度 \\
JCS $=200$
\end{tabular} & DBI & 509日 & 所見な & $\begin{array}{l}\text { 軽度右片 } \\
\text { 麻㾝 }\end{array}$ & $\begin{array}{ll}\text { 運動 } 91 \\
\text { 㨏知 } 31 \\
\text { 全 } 122\end{array}$ & $\begin{array}{l}\text { 推定IQ } \\
70 \sim 79\end{array}$ \\
\hline 症例 10 & 32歳 & 男性 & 会社員 & 14年 & 31 歳 & $\begin{array}{l}\text { 交通事故 } \\
\text { 歩行中 }\end{array}$ & \begin{tabular}{|c|} 
重度 \\
JCS $=200$
\end{tabular} & DBI & 273日 & 所見なし & \begin{tabular}{|l} 
軽度右片 \\
麻㾝
\end{tabular} & $\begin{array}{l}\text { 運動 } 90 \\
\text { 缶 } 29 \\
\text { 全 } 119\end{array}$ & $\begin{array}{l}\text { VIQ } 84 \\
\text { PIQ 85 } \\
\text { FIQ } 85\end{array}$ \\
\hline 症例 11 & 23歳 & 男性 & 会社員 & 16 年 & 22 歳 & $\begin{array}{c}\text { 交通事故 } \\
\text { 歩行中 }\end{array}$ & \begin{tabular}{c|} 
重度 \\
JCS $=100$
\end{tabular} & $\begin{array}{c}\text { DBI } \\
\text { rt.AEDH }\end{array}$ & 391日 & $\begin{array}{c}\text { 右前頭葉 } \\
\text { 右頭頂葉 } \\
\text { 左前頭葉 } \\
\text { 左中大脳脚 }\end{array}$ & $\begin{array}{c}\text { 左下肢麻 } \\
\text { 㾝 }\end{array}$ & \begin{tabular}{|l} 
運動 89 \\
諰知 32 \\
全 121 \\
\end{tabular} & $\begin{array}{l}\text { VIQ } 87 \\
\text { PIQ 47 } \\
\text { FQ 67 }\end{array}$ \\
\hline 症例 12 & 23歳 & 男性 & 学生 & 16年 & 22歳 & $\begin{array}{l}\text { 交通事故 } \\
\text { バイク運転 }\end{array}$ & \begin{tabular}{|c|} 
重度 \\
JCS $=100$
\end{tabular} & $\mathrm{DBI}$ & 200日 & 左前頭葉 & 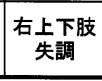 & \begin{tabular}{|l|l} 
運動 91 \\
櫭知 29 \\
全 120 \\
\end{tabular} & $\begin{array}{l}\text { VIQ 101 } \\
\text { PIQ } 85 \\
\text { FIQ 94 } \\
\end{array}$ \\
\hline \multirow{2}{*}{ 3期生 } & \multirow{2}{*}{\begin{tabular}{|c|} 
通プロ開始時 \\
年齢
\end{tabular}} & \multirow[b]{2}{*}{ 性別 } & \multirow[b]{2}{*}{ 職業 } & \multirow{2}{*}{$\begin{array}{l}\text { 教育 } \\
\text { 年数 }\end{array}$} & \multirow{2}{*}{$\begin{array}{c}\text { 受罂時 } \\
\text { 年齢 }\end{array}$} & \multirow{2}{*}{ 受蘩原因 } & \multicolumn{2}{|c|}{ 受侮時 } & 受㗹から通 & \multicolumn{4}{|c|}{ 通院プログラム開始時 } \\
\hline & & & & & & & 重症度 & 診断 & $\left|\begin{array}{|l}\text { 院プロ寒施 } \\
\text { までの期間 }\end{array}\right|$ & 挫傷部位(MRI) & $\begin{array}{l}\text { 身体: } \\
\text { 通動系 }\end{array}$ & FIM & WAIS-R \\
\hline 症例13 & 20歳 & 女性 & \begin{tabular}{|l} 
専門学校 \\
退学後
\end{tabular} & 13年 & 19歳 & $\begin{array}{c}\text { 交通事故 } \\
\text { 自動車同乗 }\end{array}$ & \begin{tabular}{|c|} 
重度 \\
JCS $=200$
\end{tabular} & DBI & 448日 & $\begin{array}{l}\text { 両側前頭葉 } \\
\text { 右頭頂葉 }\end{array}$ & 左片麻㾝 & \begin{tabular}{|l|} 
運動 91 \\
㑇知 32 \\
全 122 \\
\end{tabular} & $\begin{array}{l}\text { VIQ 83 } \\
\text { PIQ 55 } \\
\text { FIQ 65 }\end{array}$ \\
\hline 症例 14 & 23歳 & 女性 & 学生 & 16 年 & 22歳 & $\begin{array}{c}\text { 交通事故 } \\
\text { 歩行中 }\end{array}$ & $\begin{array}{c}\text { 重度 } \\
\text { GCS }=4\end{array}$ & DBI & 423日 & 所見な & 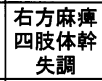 & $\begin{array}{l}\text { 運動 } 91 \\
\text { 畉 } 34 \\
\text { 全 } 125 \\
\end{array}$ & $\begin{array}{l}\text { VIQ } 92 \\
\text { PIQ } 56 \\
\text { FIQ } 77 \\
\end{array}$ \\
\hline 症例15 & 30 歳 & 男性 & 自営業 & 12年 & 29歳 & 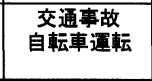 & $\begin{array}{l}\text { 中等度 } \\
\text { JCS }=10\end{array}$ & DBI & 423日 & 所見な & & $\begin{array}{l}\text { 通動 } 91 \\
\text { 諰知 } 34 \\
\text { 全 } 125\end{array}$ & $\begin{array}{l}\text { VIQ } 93 \\
\text { PIQ } 79 \\
\text { FQ } 86\end{array}$ \\
\hline 症例 16 & 23歳 & 男性 & 学生 & 12年 & 17歳 & $\begin{array}{l}\text { 交通事故 } \\
\text { バイク連転 }\end{array}$ & \begin{tabular}{|c|} 
重度 \\
$J C S=200$
\end{tabular} & DBI & 2365日 & $\begin{array}{l}\text { 右大脳半球 } \\
\text { の委縮 }\end{array}$ & $\begin{array}{l}\text { 左片麻瘟 } \\
\text { 体幹失調 } \\
\text { 檴音障害 } \\
\end{array}$ & $\begin{array}{l}\text { 運動 } 64 \\
\text { 到 } 24 \\
\text { 全 } 88 \\
\end{array}$ & PIQ 46 \\
\hline 症例 17 & 21歳 & 男性 & 学生 & 13年 & 20 歳 & $\begin{array}{l}\text { 交通事故 } \\
\text { パイク運転 }\end{array}$ & $\begin{array}{c}\text { 重度 } \\
\text { JCS }=200\end{array}$ & DBI & 340日 & 右頭頂葉 & & $\begin{array}{l}\text { 運動 } 91 \\
\text { 缺知 } 29 \\
\text { 全 } 120 \\
\end{array}$ & $\begin{array}{l}\text { VIQ } 67 \\
\text { PIQ } 79 \\
\text { FIQ } 62 \\
\end{array}$ \\
\hline 症例 18 & 19歳 & 男性 & 学生 & 13年 & 19歳 & $\begin{array}{c}\text { 交通事故 } \\
\text { 自動車同乗 }\end{array}$ & $\begin{array}{c}\text { 重度 } \\
\text { JCS }=100\end{array}$ & DBI & 250日 & $\begin{array}{c}\text { 右側頭葉 } \\
\text { 右後頭葉 } \\
\text { 両側基底核 }\end{array}$ & & $\begin{array}{l}\text { 運動 } 91 \\
\text { 锶知 } 32 \\
\text { 全 } 123\end{array}$ & $\begin{array}{l}\text { VIQ } 79 \\
\text { PIQ } 59 \\
\text { FIQ } 65\end{array}$ \\
\hline
\end{tabular}

WAIS-R=Wechsler Adult Intelligence Scale revised, MMSE=mini-mental state examination

DBI=Diffuse Brain injury (びまん性脳損偒), AEDH=acute epidural hematoma（急性硬膜外血腫）, ASDH=acute subdural hematoma（急性硬膜下血腫）

JCS=Japan Coma Scale, GCS=Glasgow Coma Scale

終了時に両群間に有意差があるかどうかで判定した.

その際，各データは項目ごとに正規分布しているもの

としていないものが混在しており，統計手法は

Mann-Whitney 検定を用いた。また，重度脳外傷者
の割合の比較には， $\chi^{2}$ 独立性の検定を用いた。

リハビリテーション医学 VOL. 40 NO. 102003 年 10 月 
表 2 プログラム参加群とコントロール群のマッチング

\begin{tabular}{lcc}
\hline & $\begin{array}{c}\text { 対象群 } \\
(18 \text { 名 })\end{array}$ & $\begin{array}{c}\text { コントロール群 } \\
(12 \text { 名 })\end{array}$ \\
\hline プログラム開始時平均年齢（歳） & $26.6 \pm 9.7$ & $28.7 \pm 10.9$ \\
受傷からプログラム開始までの平均期間 (日) & $527.3 \pm 512.6$ & $487.6 \pm 125.9$ \\
\hline 重度脳外傷者の割合 & 18 名中 16 名 & 12 名中 10 名 \\
\hline プログラム開始時 FIM 運動合計の平均 & $87.7 \pm 7.6$ & $89.3 \pm 3.9$ \\
プログラム開始時 FIM 認知合計の平均 & $29.6 \pm 3.1$ & $29.7 \pm 3.9$ \\
\hline
\end{tabular}

重症脳外傷者の割合は両群間に有意差なし（ $\chi^{2}$ 独立性の検定， $p>0.05 ）$

その他項目いずれも両群間に有意差なし（Mann-Whitney 検定， $p>0.05 ）$

表 3 通院リハプログラムの内容と関連した職種

\begin{tabular}{|c|c|c|}
\hline 主な関連職種 & 各セッションの内容 & 頻度 \\
\hline 医師・看護師 & 健康相談・診察・障害の説明 & 毎回 \\
\hline ソーシャルワーカー & $\begin{array}{l}\text { 医療相談（社会資源の情報提供） } \\
\text { 地域・企業との調整 }\end{array}$ & $\begin{array}{l}\text { 毎回 } \\
\text { 随時 }\end{array}$ \\
\hline 臨床心理士および言語聴覚士 & 社会技能訓練（SST） & 週 1 回 \\
\hline 職能指導員 & $\begin{array}{l}\text { 就労能力評価 } \\
\text { 園芸療法 } \\
\text { ロールプレイ (営業) }\end{array}$ & $\begin{array}{c}\text { 初回 } \\
2 \text { 週に } 1 \text { 回 } \\
2 \text { 週に } 1 \text { 回 }\end{array}$ \\
\hline 理学療法士 & 身体能力の評価および応用動作訓練 & 2 週に 1 回 \\
\hline 体育訓練指導員 & 各種スポーツ & 2 週に 1 回 \\
\hline 作業療法士 & 作業療法（主に陶芸） & 2 週に 1 回 \\
\hline 更生施設生活指導員 & $\begin{array}{l}\text { 社会資源の情報提供 } \\
\text { 料理実習 }\end{array}$ & $\begin{array}{l}2 \text { 週に } 1 \text { 回 } \\
2 \text { 週に } 1 \text { 回 }\end{array}$ \\
\hline 全職種 & $\begin{array}{l}\text { ハイキング立案・実行 } \\
\text { 患者・家族との定期的話し合い } \\
\text { (障害の説明・方針の提案) } \\
\text { 福祉施設見学 }\end{array}$ & $\begin{array}{c}3 \text { 回 } \\
3 \text { カ月に } 1 \text { 回 } \\
1 \text { 回 }\end{array}$ \\
\hline
\end{tabular}

\section{結 果}

\section{1. プログラム参加群の FIM・FAM 下位項目の変}

\section{化（表 4）}

表 4 に, FIM の下位項目 18 および FAM の下位項 目 12 の中，プログラム前後で変化がみられた項目を 抽出し, 症例ごとに記した.コミュニケーションに関 する項目の合計点は, 4 名が不変，改善が 14 名で, 悪化したものはなかった。また，社会認知に関する項 目の合計点は 18 名全例で改善していた。

2. CIQ 各項目の変化とプログラム終了時転帰, そ の後の方針の比較（表 5,6 ）

プログラム参加群 18 名中, 16 名で CIQ 合計点の 改善が見られた。一方コントロール群では，12 名中 4 名で改善があった。

プログラム参加群 18 名中 6 名 $(33.3 \%)$ が，何ら
かの就労・就学を果たした. 一方コントロール群で は，復学者は 12 名中 2 名（16.7\%）であった。この 場合の就労・就学とは, 週 5 日以上のフルタイム就 労，就学および福祉就労を指している。

プログラム参加群では全例 $(100 \%)$, 当院外来通院 以後の社会参加の方針が決まった。一方コントロール 群で社会参加の方針が決まったのは 12 名中 8 名 （66.7\%）であったこの場合の方針とは，就労・就 学，もしくは福祉施設利用の具体的な目処のことを指 している。

3. 2 群間の FIM・FAM, CIQ の変化の統計学的 比較 (表 7,8)

プログラム終了時に，プログラム参加群においてコ ントロール群と比較して有意な改善があったのは, FAM 下位項目の注意・集中と社会的交流および CIQ の生産性と合計点であった.（Mann-Whitney 検定, 
表 4 通院プログラム参加者の FIM・FAM の変化

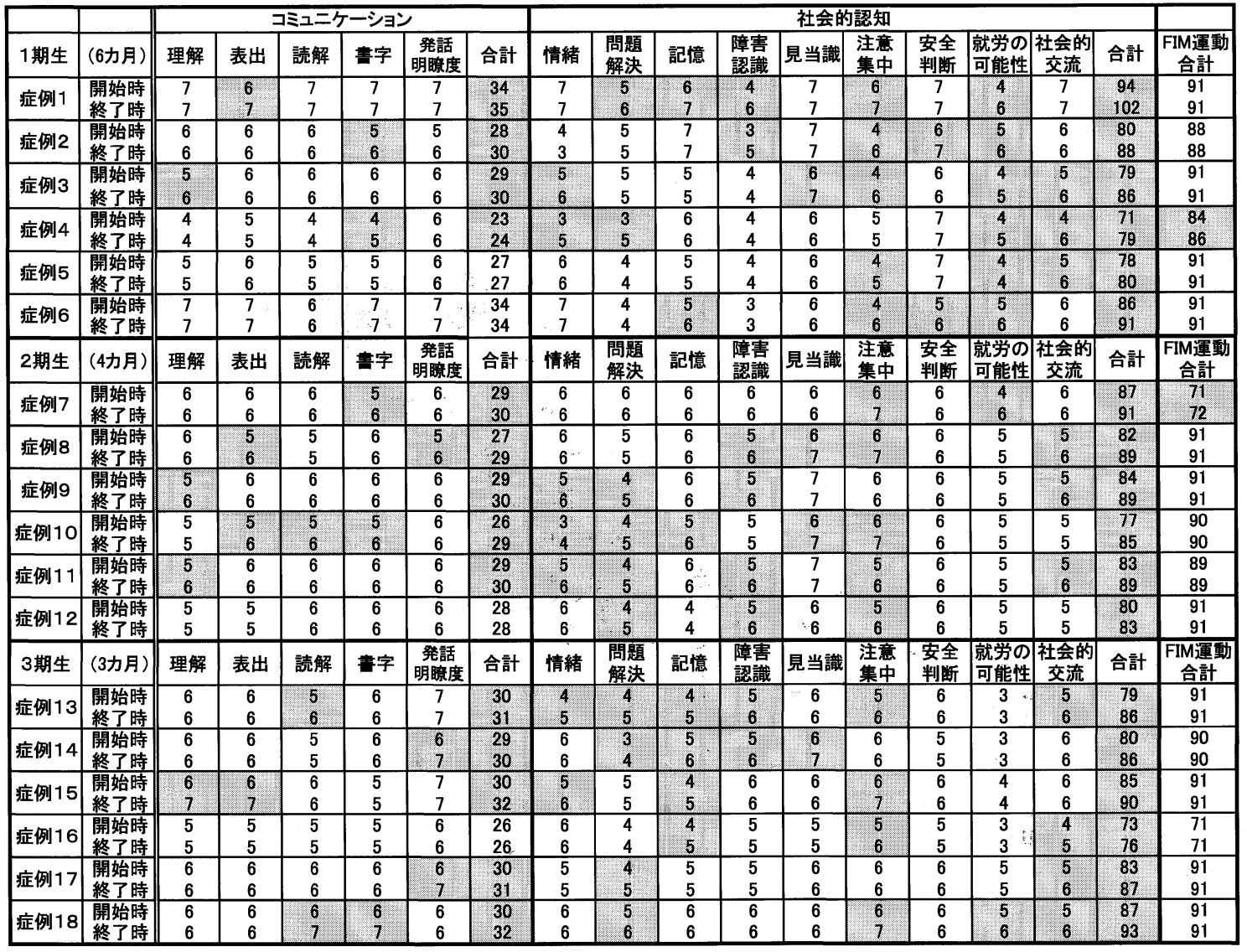

(灰色の部分は改善した項目)

$p<0.05)$

\section{考察}

当院で，通院プログラムを開始した経緯を説明す る.脳外傷後に主たる後遺症として高次脳機能障害を 残した若者の場合, 3 力月程度の入院では社会復帰に 向けた援助を十分に行えないことが多い．福祉施設な どの利用を考えたとしても，高次脳機能障害者の場合 は制度上，利用できる社会資源が少ない ${ }^{11,12)}$ 。また患 者本人が, 退院後さらに福祉施設へ入所して長期的訓 練を受けることに同意しない場合が多い，そこでやむ なく, 従来通りの理学療法や作業療法の外来治療を個 別に継続する場合が多かった，しかし，この場合，長 期的な視点から復職・復学の問題を調整し, 復職や復 学が困難な場合の支援方針を決めるシステムが存在せ ず，患者は長い時間を無為に過ごす結果になってい た.
通院プログラムは, 2001 年から 3 年間, 厚生労働 省が行う「高次脳機能障害支援モデル事業」に参加す る中で，上記の課題を解決するために試行的に行った 事業である。

今回のプログラム参加者 18 名は, いずれも $\mathrm{ADL}$ がほぼ自立していた。しかし急性期には，その大半が びまん性脳損傷による重度の脳外傷を経験していた。 結果として，プログラム開始時の FIM・FAM の認 知項目の評価点は，身体障害が軽度にもかかわらず低 い傾向にあった。これらの症例は, 退院後も社会参加 できないでいたが，その要因は，コミュニケーショ ン，認知打よびその他の心理社会的障害であった。

通院プログラムは，参加者に定期的な日課を提供 し，その後の社会復帰支援を視野に継続的な援助を行 った.

その結果, プログラム参加群 18 例中 16 例で $\mathrm{CIQ}$ 合計点の改善が見られた.コントロール群との比較で 
表 5 通院プログラム参加者の $\mathrm{CIQ}$ の変化と終了時転帰，その後の方針

\begin{tabular}{|c|c|c|c|c|c|c|c|}
\hline \multirow{2}{*}{ 1期生 } & \multirow{2}{*}{ （6力月） } & \multicolumn{4}{|c|}{ CIQ } & \multirow{2}{*}{ 終了時転帰 } & \multirow{2}{*}{ その後の方針 } \\
\hline & & 豕廷内沽野 & 社会活動 & 生産性 & 合計 & & \\
\hline 症例1 & 開始時 & 4 & 7 & 0 & 11 & & \\
\hline \multirow{2}{*}{ 症例2 } & 開始時 & 4 & 8 & 1 & 13 & & \\
\hline & 終了時 & 5 & 9 & 4 & 18 & 外来通院 & 復職 \\
\hline \multirow{2}{*}{ 症例3 } & 開始時 & 3 & 7 & 1 & 11 & & \\
\hline & 終了時 & 4 & 8 & 4 & 16 & 部分復職 & 復職 \\
\hline \multirow{2}{*}{ 症例4 } & 開始時 & 0 & 5 & 1 & 6 & & \\
\hline & 終了時 & 0 & 6 & 4 & 10 & 外来通院 & 更生施設通所 \\
\hline \multirow{2}{*}{ 症例5 } & 開始時 & 1 & 10 & 2 & 13 & & \\
\hline & 終了時 & 1 & 11 & 3. & 15 & 更生施設 & 更生施設入所 \\
\hline \multirow{2}{*}{ 症例6 } & 開始時 & 2 & 6 & 4 & 12 & & \\
\hline & 終了時 & 2 & 6 & 4 & 12 & 外来通院 & 復職 \\
\hline 2期生 & (4力月) & 家庭内活動 & 社会活動 & 生産性 & 合許 & 終了時転慢 & その後の方針 \\
\hline \multirow{2}{*}{ 症例7 } & 開始時 & 0 & 7 & 1 & 8 & & \\
\hline & 終了時 & 0 & 9 & 4 & 13. & 外来通院 & 福祉施設通所 \\
\hline \multirow{2}{*}{ 症例8 } & 開始時 & 4 & 7 & 1 & 12 & & \\
\hline & 終了時 & 4 & 11 & 5 & 20 & 外来通院 & 作莱所通所 \\
\hline \multirow{2}{*}{ 症例9 } & 開始時 & 5 & 8 & 4 & 17 & & \\
\hline & 終了時 & 5 & 8 & 4 & 17 & 外来通院 & 㪀職 \\
\hline \multirow{2}{*}{ 症例10 } & 開始時 & 8 & 8 & 3 & 19 & & \\
\hline & 終了時 & 8 & 8 & 6 & 22 & 復職 & 就学継続 \\
\hline \multirow{2}{*}{ 症例11 } & 開始時 & 6 & 10 & 3 & 19 & & \\
\hline & 終了時 & 6 & 11 & 4 & 21 & 外来通院 & 專門学校受験 \\
\hline \multirow[t]{2}{*}{ 症例12 } & 開始時 & 4 & 7 & 3 & 14 & & \\
\hline & 終了時 & 4 & 9 & 6 & 19 & 能開校 & 能開校入所継続 \\
\hline 3期生 & (3力月) & 家庭内活動 & 社会活動 & 生产性 & 合許 & 終了時転㛿 & その後の方針 \\
\hline \multirow{2}{*}{ 症例13 } & 開始時 & 2 & 6 & 0 & 8 & & \\
\hline & 終了時 & 2 & 7 & 4 & 13 & 外来通院 & 授産所通所 \\
\hline \multirow{2}{*}{ 症例14 } & 開始時 & 1 & 6 & 2 & 9 & & \\
\hline & 終了時 & 2 & 6 & 6 & 14 & 更生施設通所 & 更生施設通所継結 \\
\hline \multirow{2}{*}{ 症例15 } & 開始時 & 6 & 10 & 2 & 18 & & \\
\hline & 終了時 & 6 & 11 & 6 & 23 & 外来通院 & 授産所通所 \\
\hline \multirow{2}{*}{ 症例16 } & 開始時 & 1 & 6 & 6 & 13 & & \\
\hline & 終了時 & 1 & 6 & 6 & 13 & 作業所通所 & 作業所通所橉続 \\
\hline \multirow{2}{*}{ 症例 17} & 開始時 & 4 & 11 & 4 & 19 & & \\
\hline & 終了時 & 6 & 11 & 6 & 23 & 大学復学 & 大学生活継続 \\
\hline \multirow[t]{2}{*}{ 症例18 } & $\begin{array}{l}\text { 開始時 } \\
\text { 終了時 }\end{array}$ & 2 & $\begin{array}{l}11 \\
11\end{array}$ & $\frac{4}{6}$ & 17 & 大学澓学 & + 学牛: \\
\hline & & & & & 19 & 人子位子 & 大宇生 \\
\hline
\end{tabular}

表 6 コントロール群の $\mathrm{CIQ}$ の変化と終了時転帰, その後の方針

\begin{tabular}{|c|c|c|c|c|c|c|c|}
\hline & \multicolumn{4}{|c|}{ CIQ } & \multirow{2}{*}{ 終了時転帰 } & \multirow{2}{*}{ その後の方針 } \\
\hline & & 家庭内活重 & 社会活動 & 生産性 & 合計 & & \\
\hline \multirow{2}{*}{ 症例 A } & 開始時 & 5 & 10 & 6 & 21 & & \\
\hline & 終了時 & 5 & 10 & 5 & 20 & 復学 & 復学継続 \\
\hline \multirow{2}{*}{ 症例B } & 開始時 & 2 & 6 & 1 & 9 & & \\
\hline & 終了時 & 3 & 6 & 2 & 11 & 外来通院 & 外来通院 \\
\hline \multirow{2}{*}{ 症例C } & 開始時 & 1 & 5 & 6 & 12 & & \\
\hline & 終了時 & 2 & 6 & 6 & 14 & 更生施設入所 & 更生ホーム入所 \\
\hline \multirow{2}{*}{ 症例D } & 開始時 & 4 & 11 & 6 & 21 & & \\
\hline & 終了時 & 4 & 11 & 6 & 21 & 大学復学 & 大学生活継続 \\
\hline \multirow{2}{*}{ 症例E } & 開始時 & 0 & 7 & 5 & 12 & & \\
\hline & 終了時 & 0 & 7 & 5 & 12 & 責護学校 & 趛讙学校継絰 \\
\hline \multirow{2}{*}{ 症例 $F$} & 開始時 & 7 & 7 & 1 & $\overline{15}$ & & \\
\hline & 終了時 & 7 & 7 & 1 & 15 & 外来通院 & 外来通院 \\
\hline \multirow{2}{*}{ 症例G } & 開始時 & 4 & 9 & 2 & 15 & & \\
\hline & 終了時 & 4 & 9 & 2 & 15 & 外来通院 & 外来通院 \\
\hline \multirow{2}{*}{ 症例 $\mathrm{H}$} & 開始時 & 4 & 9 & 3 & 16 & & \\
\hline & 終了時 & 5 & 9 & 3 & 17 & 外来通院 & 作業所通所 \\
\hline \multirow{2}{*}{ 症例I } & 開始時 & 4 & 9 & 5 & 18 & & \\
\hline & 終了時 & 4 & 9 & 5 & 18 & 外来通院 & 復職 \\
\hline \multirow{2}{*}{ 症例J } & 開始時 & 1 & 7 & 2 & 10 & & \\
\hline & 終了時 & 1 & 7 & 2 & 10 & 外来通院 & 就労 \\
\hline \multirow{2}{*}{ 症例K } & 開始時 & 3 & 7 & 2 & 12 & & \\
\hline & 終了時 & 3 & 8 & 2 & 13 & 外来通院 & 更生施設入所 \\
\hline \multirow[t]{2}{*}{ 症例L } & 開始時 & 5 & 5 & 2 & 12 & 等来䦽院 & 保来俑院 \\
\hline & 終了時 & 5 & 5 & 2 & 12 & 外来通院 & 外来通院 \\
\hline
\end{tabular}

(灰色の部分は改善した項目)

も，CIQ 生産性に有意な改善を認めた。このことは, 同プログラムが医療だけでなく, 福祉, 労働, 教育サ ービスとの連携を強化するという目的に沿う内容にな
っていると思われた.

さて, 通院プログラム参加者は, 全員が FIM・ FAM のコミュニケーション, 社会的認知項目のいず 
表 7 FIM・FAM 各項目の比較

\begin{tabular}{|c|c|c|c|}
\hline FIM-FAM & & $\begin{array}{l}\text { 対象群 } \\
(18 \text { 例) }\end{array}$ & $\begin{array}{c}\text { コントロール群 } \\
\text { (12例) }\end{array}$ \\
\hline 理解 & $\begin{array}{l}\text { 開始時 } \\
\text { 終了時 }\end{array}$ & $\begin{array}{l}5.6 \pm 0.8 \\
5.8 \pm 0.8\end{array}$ & $\begin{array}{l}6.0 \pm 1.0 \\
6.3 \pm 0.6\end{array}$ \\
\hline 表出 & $\begin{array}{l}\text { 開始時 } \\
\text { 終了時 }\end{array}$ & $\begin{array}{l}5.8 \pm 0.5 \\
6.0 \pm 0.6\end{array}$ & $\begin{array}{l}6.0 \pm 1.0 \\
6.1 \pm 0.9\end{array}$ \\
\hline 読解 & $\begin{array}{l}\text { 開始時 } \\
\text { 終了時 }\end{array}$ & $\begin{array}{l}5.6 \pm 0.7 \\
5.8 \pm 0.7\end{array}$ & $\begin{array}{l}6.1 \pm 0.9 \\
6.2 \pm 0.7\end{array}$ \\
\hline 書字 & $\begin{array}{l}\text { 開始時 } \\
\text { 終了時 }\end{array}$ & $\begin{array}{l}5.7 \pm 0.8 \\
5.9 \pm 0.6\end{array}$ & $\begin{array}{l}6.2 \pm 0.9 \\
6.3 \pm 0.8\end{array}$ \\
\hline 発話明瞭度 & $\begin{array}{l}\text { 開始時 } \\
\text { 終了時 }\end{array}$ & $\begin{array}{l}6.1 \pm 0.6 \\
6.3 \pm 0.5 \\
\end{array}$ & $\begin{array}{l}6.3 \pm 0.9 \\
6.3 \pm 0.9 \\
\end{array}$ \\
\hline コミュニケーション合計 & $\begin{array}{l}\text { 開始時 } \\
\text { 終了時 }\end{array}$ & $\begin{array}{l}28.8 \pm 2.6 \\
29.9 \pm 2.6\end{array}$ & $\begin{array}{l}30.5 \pm 4.0 \\
31.0 \pm 3.4\end{array}$ \\
\hline 情緒 & $\begin{array}{l}\text { 開始時 } \\
\text { 終了時 }\end{array}$ & $\begin{array}{l}5.3 \pm 1.2 \\
5.7 \pm 1.0\end{array}$ & $\begin{array}{l}5.5 \pm 0.9 \\
5.7 \pm 0.8\end{array}$ \\
\hline 問題解決 & $\begin{array}{l}\text { 開始時 } \\
\text { 終了時 }\end{array}$ & $\begin{array}{l}4.3 \pm 0.8 \\
4.9 \pm 0.6\end{array}$ & $\begin{array}{l}5.0 \pm 0.6 \\
5.2 \pm 0.7\end{array}$ \\
\hline 記憶 & $\begin{array}{l}\text { 開始時 } \\
\text { 終了時 }\end{array}$ & $\begin{array}{l}5.3 \pm 0.9 \\
5.7 \pm 0.8\end{array}$ & $\begin{array}{l}5.7 \pm 0.9 \\
5.8 \pm 0.9\end{array}$ \\
\hline 障害認識 & $\begin{array}{l}\text { 開始時 } \\
\text { 終了時 }\end{array}$ & $\begin{array}{l}4.7 \pm 0.9 \\
5.3 \pm 1.0\end{array}$ & $\begin{array}{l}5.3 \pm 0.6 \\
5.8 \pm 0.8\end{array}$ \\
\hline 見当識 & $\begin{array}{l}\text { 開始時 } \\
\text { 終了時 }\end{array}$ & $\begin{array}{l}6.2 \pm 0.5 \\
6.4 \pm 0.6\end{array}$ & $\begin{array}{l}6.1 \pm 1.0 \\
6.3 \pm 1.1\end{array}$ \\
\hline 注意·集中* & $\begin{array}{l}\text { 開始時 } \\
\text { 終了時 }\end{array}$ & $\begin{array}{l}5.3 \pm 0.8 \\
6.2 \pm 0.6\end{array}$ & $\begin{array}{l}5.5 \pm 0.7 \\
5.6 \pm 0.7\end{array}$ \\
\hline 安全判断 & $\begin{array}{l}\text { 開始時 } \\
\text { 終了時 }\end{array}$ & $\begin{array}{l}6.0 \pm 0.6 \\
6.1 \pm 0.6\end{array}$ & $\begin{array}{l}6.0 \pm 1.0 \\
6.2 \pm 1.0\end{array}$ \\
\hline 就労の可能性 & 開始時 & $\begin{array}{l}4.3 \pm 0.8 \\
4.8 \pm 1.0\end{array}$ & $\begin{array}{l}4.5 \pm 0.7 \\
4.7 \pm 0.8\end{array}$ \\
\hline 社会的交流* & $\begin{array}{l}\text { 開始時 } \\
\text { 終了時 }\end{array}$ & $\begin{array}{l}5.3 \pm 0.8 \\
5.9 \pm 0.5\end{array}$ & $\begin{array}{l}5.2 \pm 0.6 \\
5.4 \pm 0.8\end{array}$ \\
\hline 社会的認知合計 & $\begin{array}{l}\text { 開始時 } \\
\text { 終了時 }\end{array}$ & $\begin{array}{l}46.7 \pm 3.4 \\
51.0 \pm 3.6\end{array}$ & $\begin{array}{l}48.7 \pm 5.8 \\
50.4 \pm 6.2\end{array}$ \\
\hline FIM運動項目合計 & $\begin{array}{l}\text { 開始時 } \\
\text { 終了時 }\end{array}$ & $\begin{array}{l}88.0 \pm 6.4 \\
88.2 \pm 6.2\end{array}$ & $\begin{array}{l}89.8 \pm 3.0 \\
90.1 \pm 2.2\end{array}$ \\
\hline
\end{tabular}

表 $8 \mathrm{CIQ}$ 各項目の比較

\begin{tabular}{|l|l||c|c|}
\hline \multicolumn{1}{|c|}{$\mathrm{CIQ}$} & & $\begin{array}{c}\text { 对象群 } \\
(18 \text { 例 })\end{array}$ & $\begin{array}{c}\text { コントロール群 } \\
(12 \text { 例 })\end{array}$ \\
\hline 家庭内活動 & 開始時 & $3.2 \pm 2.2$ & $3.3 \pm 2.0$ \\
終了時 & $3.5 \pm 2.3$ & $3.6 \pm 1.9$ \\
\hline 社会活動 & 開始時 & $7.8 \pm 1.9$ & $7.7 \pm 1.9$ \\
& 終了時 & $8.7 \pm 2.0$ & $7.8 \pm 1.8$ \\
\hline 生産性* & 開始時 & $2.3 \pm 1.6$ & $3.4 \pm 2.0$ \\
\hline \hline & 終了時 & $4.8 \pm 1.0$ & $3.4 \pm 1.8$ \\
\hline 合計* & 開始時 & $13.3 \pm 4.1$ & $14.4 \pm 4.0$ \\
\hline
\end{tabular}

*有意差あり(Mann-WhitneyのU検定, $p<0.05$ )

れかで改善を示していた。また，プログラム参加群と コントロール群の比較では, 参加群は FIM・FAM 下位項目の注意・集中, 社会的交流が有意に改善して いた。この結果は，プログラム中の指導によって定期 的日課を継続したことが注意・耐久性の向上に，また プログラム中に行った Social Skill Training（SST） が社会性向上に結びついた可能性を示している。しか し, これらの変化がすべて通院プログラムの効果であ
るかについて判断できない部分もある．参加者の選抜 の際に，グループプログラムによって高い効果が得ら れると考えられた症例が選ばれていた可能性も考えら れる。ささら FIM・FAM は，実際に行っている日 常生活自立度を評価することが目的であるが，判定に 主観が入りやすい．すなわち通院プログラムを通して 評価者と多くの時間を共有した参加群については，コ ントロール群には観察できない, わずかな変化を抽出 できたこともあったかと考えられる。

当院の通院プログラムの模範となったプログラムと して, ニューヨーク大学の Brain Injury Day Treatment Program がある ${ }^{13,14)}$. やはり, 後天性脳損傷者 に起きている多面的な神経認知, 神経行動および対人 行動の障害に焦点を当てたものである. 同プログラム は 8 名の専属スタッフによる, 1 日 5 時間, 週 4 回, 20 週間を 1 サイクルとした, 独立採算性の集中的プ ログラムであり, 結果として, 多額の費用がかかる.

我が国で同様のプログラムを行う場合, 医療経済あ るいは病院経営の立場から, いつ, どこで, 誰によ り，どのような手法で行われるべきか，十分な検討を 要する．当院の通院プログラムの実施に欠かせないス タッフとしては, 臨床心理士, 職能指導員, 体育訓練 指導員, 医療ソーシャルワーカーなどの診療報酬対象 外の職種があった。今後, 同様のプログラムを病院で 実施する場合, 少しでも経営的負担を少なくするため に, 診療報酬の対象となる理学療法士 (PT), 作業療 法士 (OT), 言語聴覚士（ST）などが行う治療に, 臨床心理士, 職能指導員, 体育訓練指導員, 医療ソー シャルワーカーなどが乗り入れる TDT model（transdisciplinary team model） アプローチ15,16) の採用が 考えられる.あるいは, プログラムを病院の治療とし てではなく, 重度身体障害者更生施設などの福祉施設 枠を利用し, 支援費から安定した収入を得ることも一 案であろう。

当院では, 脳外傷リ八を長年行ってきた経緯から， 国のモデル事業終了後も通院プログラムの継続を計画 している. 症例が増すことで, プログラム内容の改善 と, より妥当な効果判定が行えることに期待してい る. 関連して, 本プログラム終了後の対象者は支援が 不要になったわけではない。そこで長期的支援を継続 できるシステムを構築することが必要と考えている。 


\section{文献}

1）神奈川リハビリテーション病院脳外傷リハビリテーシ ヨンマニュアル編集委員会 : 脳外傷リハビリテーショ ンマニュアル. 医学書院, 東京, 2001

2) 大橋正洋: 脳外傷リハビリテーションの課題. リハ医 学 $2000 ; 37: 121-128$

3）渡邊 修, 大橋正洋, 橋本圭司 : 脳外傷回復期の包括的 リハビリテーションとその成果. リハ医学 $2001 ; 38$ : 892-897

4) Prigatano GP, Fordyce DJ, Zeiner HK, Roueche JR, Pepping M, Wood BC: Neuropsychological rehabilitation after closed head injury in young adult. J Neurol Neurosurg Psychiatry 1984 ; 47 : 505-513

5) Klonoff PS, Lamb DG, Henderson SW, Shepherd J : Outcome assessment after milieu-oriented rehabilitation : new considerations. Arch Phys Med Rehabil 1998; 79 : 684-690

6) Armengol CG: A multimodal support group with Hispanic traumatic brain injury survivors. J Head Trauma Rehabil 1999; 14: 233-246

7) Wiseman-Hakes C, Stewart ML, Wasserman R, Schuller R: Peer group training of pragmatic skills in adolescents with acquired brain injury. J Head Trauma Rehabil 1998 ; 13: 23-36

8) Ben-Yishay Y, Diller L: Cognitive Remediation in Traumatic brain Injury: update and Issues. Arch Phys Med Rehabil 1993 ; 74 : 204-213

9）渡邊 修, 大橋正洋, 橋本圭司, 殿村 暁, 藤縄光留, 坂 本久恵, 生方克之, 安保雅博, 宮野佐年, 米本恭三 : 脳外 傷者に対する通院リハビリテーションプログラムの試 み. 総合リハ $2003 ; 31: 669-675$
10) Gennarelli TA, Spielman GM, Langfitt TW, Gildenberg PL, Harrington T, Jane JA, Marshall LF, Miller JD, Pitts LH : Influence of the type of intracranial lesion on outcome from severe head injury. J Neurosurg $1982 ; \mathbf{5 6}: 26-32$

11）橋本圭司, 根本栄美子, 大橋正洋, 生方克之, 渡邊 修, 上久保毅, 宮野佐年: 神奈川リハビリテーション病院 における脳損傷者の障害者手帳取得状況一障害の種 類. 一等級と FIM 得点の調査一. 臨床リハ $2003 ; 12$ : 180-184

12）橋本圭司, 大橋正洋, 渡邊 修: 記憶障害者への環境的 対応と社会資源について. 総合リハ $2002 ; 30$ : 329334

13) Ben-Yishay Y, Diller L, Daniels-Zide E: 米国におけ る神経心理学的リハビリテーション (大橋正洋 訳). リハビリテーション MOOK (千野直一, 安藤德彦 編) 4, 高次脳機能障害とリハビリテーション, 第 1 版, $2001 ;$ pp 1-7

14）先崎 章, 枝久保達夫, 新井美弥子: ニューヨーク大学 医療センター・ラスクー「脳外傷者外来通院治療プロ グラム」で行われている集団を利用した認知・心理療 法一. 臨床リハ $1996 ; 8$ : 559-565

15) King JC, Nelson TR, Heye ML, Tururro TC, Titus MND : Prescriptions, referrals, order writing, and the rehabilitation team function. in Rehabilitation Medicine: Principles and Practice (ed by Delisa JA, Gans BM), 3 rd Ed, Lippincott-Raven Publishers, Philadelphia, 1998; pp 269-285

16）橋本圭司, 大橋正洋, 渡邊 修, 宮野佐年: 重度認知・ 行動障害者に対する相互乗り入れチームアプローチ. リハ医学 $2002 ; 39: 253-256$ 